\title{
Performance Analysis of Solar Assisted Food Storage Heater with Different Insulators
}

\author{
Rashmi Sapali \\ Department of Mechanical Engineering \\ G.H. Raisoni College of Engineering, Wagholi, Pune, India \\ Dr. R. R. Arakerimath \\ Department of Mechanical Engineering \\ G.H. Raisoni College of Engineering, Wagholi, Pune, India
}

\begin{abstract}
This dissertation presents result of the experimental Study of Solar Assisted Food Heater. The parameters varied for the experimentation are hot water input (10 and 12 litres of hot water), the insulators used (Glasswool and Polystyrene insulators). The measurement of heat transfer is very critical and depends on estimation of average heat transfer coefficient. The experimentation results are presented in terms of various heat transfer parameters such as heat transfer coefficient inside of box (hi), heat transfer coefficient outside the box (ho). The results of heat loss of setup with glasswool insulation and results of polystyrene insulation are compared with results of setup without insulation. The results obtained are compared with the results obtained after theoretical calculations. The validation is carried out with standard literature available for solar water heater and solar cooker and lumped heat capacity. It is observed from experimental result that maximum heat loss occurs when 12 litres of hot water is used with setup without insulation $(Q=51.509 W)$. Using glasswool as insulator, the heat loss reduced up to $\mathbf{5 1 . 1 0 \%}$. Furthermore, after replacing the glasswool insulator with polystyrene insulator, the heat loss is further reduced to $\mathbf{5 4 . 4 4 \%}$. Thus, maximum heat loss is prevented using polystyrene insulator.
\end{abstract}

Keywords - Solar water heater, Food warming equipments, Insulators, heat loss prevention.

\section{INTRODUCTION}

Water which is heated by the sun is used for various applications finds major application in Tropical counties like India, China, Sri Lanka etc. which receive a descent amount of sunlight for maximum duration of the year. The best known application will be in the residential application to provide domestic hot water, solar hot water also has industrial applications, e.g. to generate electricity. Simple and cheap designs are suitable for climates that are hot and can hence be considered as an appropriate technology for hot places like these.

In order to heat water using solar energy, a collector, which is usually situated on the top of the building or a wall facing the sun (mostly west), heats the working fluid that is either pumped or driven by natural convection through it. The collector is generally made up of a glass-topped insulated box with a flat solar absorber made of sheet metal, attached to copper heat exchanger pipes. It is dark in color or there is a set of metal tubes which is surrounded by an evacuated glass cylinder. For industrial application, a parabolic mirror is used which can concentrate sunlight that falls over it on the tube. This heated water is stored in an insulated hot water storage tank. The volume of this tank is larger with solar heating systems so that hot water is provided irrespective of bad weather condition. The optimum final temperature for the solar collectors is lower than a typical immersion or combustion heater. The hot water from the tank acts like the heat transfer fluid for the absorber. Generally, there is a separate loop of fluid containing antifreeze and a corrosion inhibitor which delivers heat to the tank through a heat exchanger. As copper has high thermal conductivity, it does not decompose (offers resistance to atmospheric and water corrosions), sealing and can be joined by soldering, and has good mechanical strength, it plays an important role in the components used in solar thermal heating and cooling systems. Copper is used in receivers and primary circuits both (pipes and heat exchangers for water tanks).

In early study made by engineers, they explain us the energy crisis all over the world and its effect in India. In developing countries like India, population of about more than $70 \%$ lives in the rural areas where more than $85 \%$ of the energy being consumed comes from non-conventional sources, the major one being fuel wood (dry wood). The increasing cost of conventional fuel in urban areas has made us look for and explore other options of other sources of energy. Solar energy which is available almost 9 months in a year, proves to be a good substitute option for nonrenewable energy source (i.e. fossil fuels). (Vishwanath K Patel, 2012). 
The use of Fresnel lens for concentrating solar energy for imaging and non-imaging application along with the possible applications of the Fresnel lens based concentrators for low pressure steam generation. . Compared with imaging systems, non-imaging systems have the merits of larger accept angles, higher concentration ratios with less volume and shorter focal length, higher optical efficiency, etc. Therefore, non-imaging design can offer better possibilities that are needed for a breakthrough of Fresnel lenses in commercial use of solar energy concentration, both in photovoltaic and thermal power conversion (Pankaj D. Menghani et al. 2014).

The idea of using solar energy in transmitting power in a wireless way, can be a green energy application. The main function in a wireless power is providing power to any electronic device wirelessly. If the efficiency of transmitting the power wirelessly is increased slightly, then wireless power transmission could become a standard means for charging any electronic gadget. Also if this transmitting is done with the help of a renewable and a clean power source such as Solar energy, it would result in saving lot of fossil fuel and the pollutions related to it can be avoided. (Saurabh Deshmukh et al., 2014).

India needs to switch from non-renewable energy source towards using renewable energy source. India has over $18 \%$ of its total population in the 15-24 age groups, there is a very high potential of developing and acquiring manpower / skilled people who can help achieve the projected targets in developing and establishing renewable energy sources. Further, a brief status and statistical analysis of the rising need of power generation is being discussed. There is a discussion on the need for inclusion of solar photo-voltaic course in the undergraduate academic syllabus for budding engineers. A brief introduction and discussion of solar energy is given as a motivation to undergraduate students. (S. Ramanan et.al, 2013).

The use of solar Photo Voltaic cells for commercial electricity generation and making this electricity cheaper than conventional method is the primary concern today. Solar energy is becoming one of the important energy in the future as a great renewable energy source. Solar cells provide various output depending on the intensity of heat that they receive. Change in temperature affects the power directly. The cost of electricity from solar PV cells is still many folds higher than the conventional power generation. So it is the need of the hour to improve the efficiency of the solar PV cells. This efficiency can be increased either by changing PV material or concentrating solar rays or by using solar tracking system. Here the author uses optimized angled collector for concentration and manual Bi-axial Sun tracking system. It is found that by using collector of optimized size and biaxial tilting of the panel, performance of the Photo Voltaic cell panel is increased tremendously. (Vijay Talekar et al., ).

\section{PROPOSED SOLUTION}

\section{A. Experimental Setup -}

In most of the cafeterias or messes, electric water heaters or stoves are used for keeping the cooked food warm. This results in continuous use of electricity and liquid petroleum gas (LPG) which is additional cost burden to bear by the owner. To reduce this extra burden I have considered solar energy as the source of warm water supply. In this setup, I have considered a small capacity model with 3 utensils for small scale application. The main aim of this setup is to keep the cooked food warm using warm water from solar water heater. Solar water heater used in residential applications is used as the source for warm water. The setup used in this application is made up of steel body, insulation and utensils for keeping cooked food.

The arrangement consists of a solar water heater, steel box with three holes on top to accommodate three steel utensils (with lid), to keep inside the container, steel container should have a tap at bottom, insulation provided for the box.

Body: A stainless steel body used for holding hot water. It should have an insulation of around $15 \mathrm{~mm}$. Thermocol is used as an insulating material. Insulators are those materials that are used for preventing heat transfer from hot water inside the body to the outside.

Solar Water Heater: Domestic solar water heaters are used for here for obtaining hot water. Water up to a temperature of $80 \mathrm{degC}$ is obtained through these water heaters.

Utensils: Considered three utensils for the experiment purpose. These utensils are used to store cooked food inside the box. 


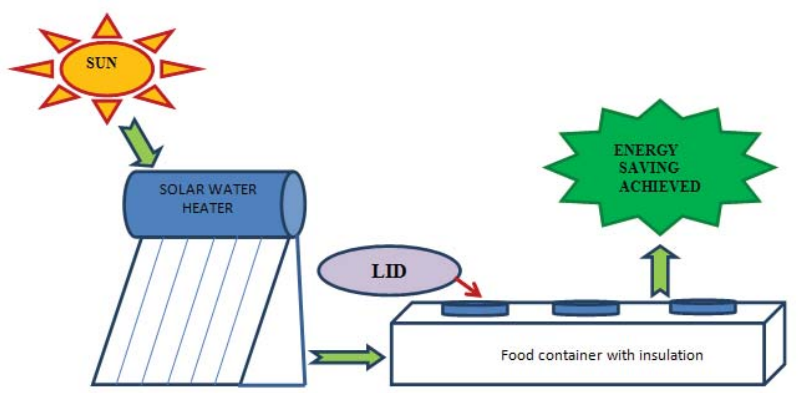

Figure 1. Schematic of the arrangement of solar assisted water heater

\section{EXPERIMENT AND RESULT}

The setup is as above as above and three types of reading are taken up. One case without insulation, one with glasswool insulation and the third case with polystyrene insulation.

Below are the readings taken from the experimental setup without any insulation. Ambient temperature is $30 \mathrm{degC}$ and 10 liters hot water is used in the box.

A. Without insulation

Table 1: Temperature Vs. Time reading for different food items

\begin{tabular}{|l|l|l|l|l|l|l|l|l|}
\hline $\begin{array}{l}\text { Material/ } \\
\text { Time }\end{array}$ & $\begin{array}{l}\mathrm{T}=0 \\
\text { mins }\end{array}$ & $\begin{array}{l}\mathrm{T}=15 \\
\text { mins }\end{array}$ & $\begin{array}{l}\mathrm{T}=30 \\
\text { mins }\end{array}$ & $\begin{array}{l}\mathrm{T}=45 \\
\text { mins }\end{array}$ & $\begin{array}{l}\mathrm{T}=60 \\
\text { mins }\end{array}$ & $\begin{array}{l}\mathrm{T}= \\
90 \\
\text { mins }\end{array}$ & $\begin{array}{l}\mathrm{T}= \\
\text { mins }\end{array}$ & $\begin{array}{l}\mathrm{T}= \\
\text { mins }\end{array}$ \\
\hline WATER & 70 & 52 & 50 & 49 & 47 & 46 & 44 & 42 \\
\hline RICE & 88 & 78 & 72 & 67 & 66 & 63 & 62 & 60 \\
\hline POTATO & 88 & 51 & 48 & 47 & 47 & 47 & 47 & 45 \\
\hline CURRY & 70 & 60 & 59 & 58 & 57 & 55 & 53 & 53 \\
\hline FACE 1 & 54.2 & 49.3 & 47.7 & 46.6 & 44.8 & 43.9 & 42.1 & 41 \\
\hline FACE 2 & 53.4 & 50.4 & 48 & 46.6 & 44.5 & 43.3 & 42.3 & 40.9 \\
\hline FACE 3 & 56 & 48 & 46.4 & 45.4 & 43.6 & 42.2 & 40.7 & 39.3 \\
\hline FACE 4 & 55.8 & 52.8 & 47 & 46.1 & 43.8 & 42.8 & 41.3 & 39.7 \\
\hline FACE 5 & 78 & 48 & 45 & 44.4 & 42.3 & 41.2 & 40.4 & 39.6 \\
\hline FACE 6 & 60 & 55 & 44.5 & 44.5 & 43.9 & 44.1 & 42 & 40.5 \\
\hline
\end{tabular}

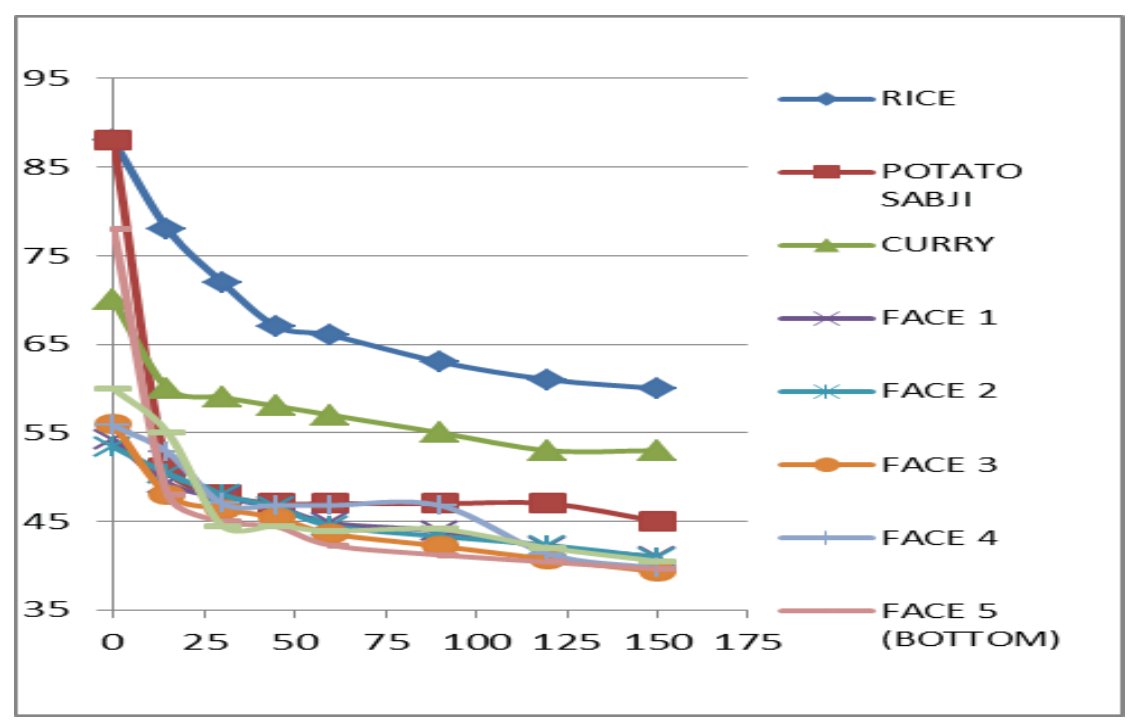

Figure 2. Graph showing temperature of food items against time. 
Figure 3. From the above observation we can see that the temperature of the food items and hot water drastically decreases and almost remains constant after $42 \mathrm{degC}$ and reaches a temperature of $40 \mathrm{degC}$ after 150 minutes. After this the water in the box needs to be replaced by fresh hot water from solar water heater.

B. With insulation.

Same setup is used with a box with insulation.

a. Thermocol Insulation

Table 2: Temperature Vs. Time reading for different food items with thermocol insulation

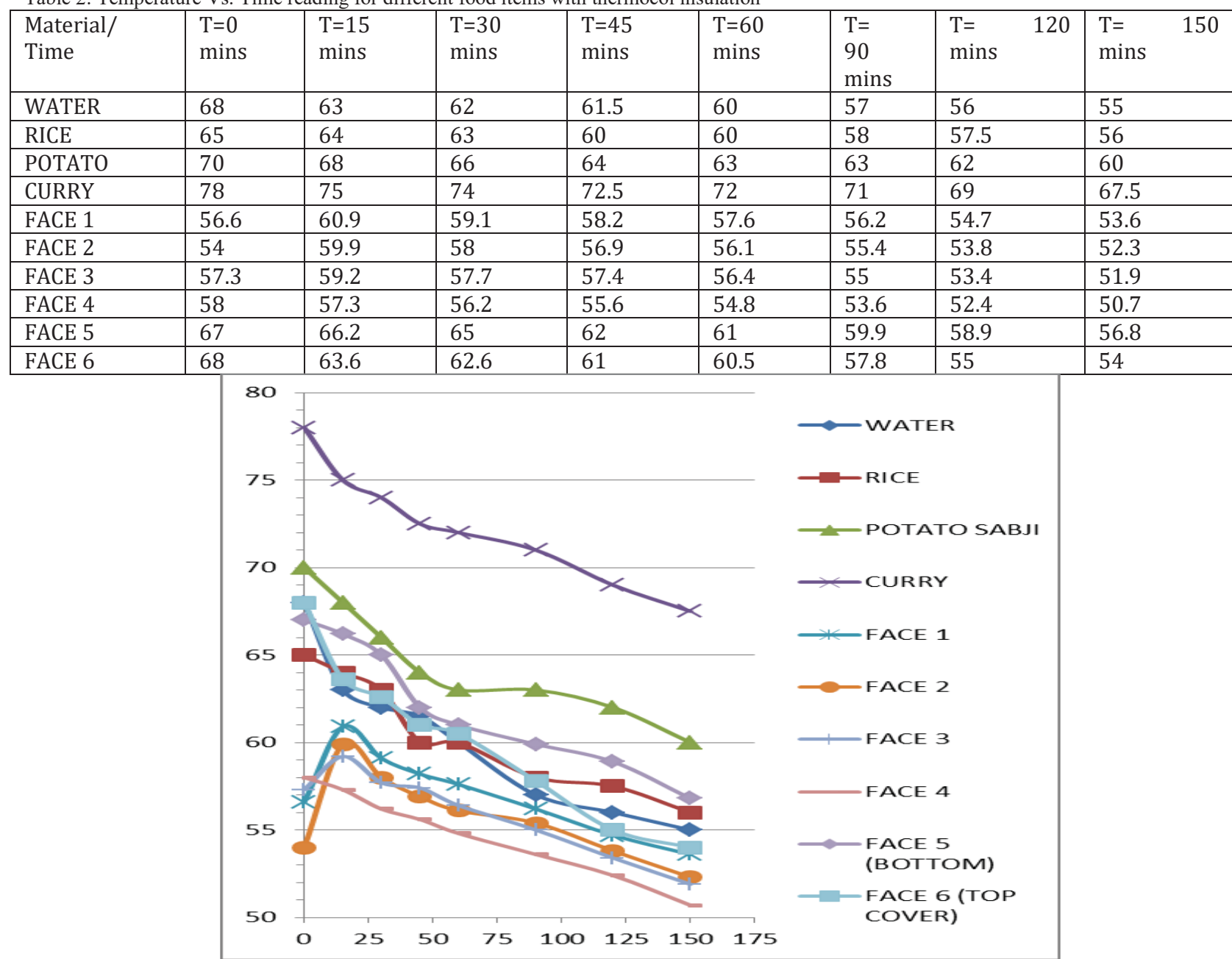

Figure 3: Graph showing temperature of food items against time with thermocol insulation

From the above observation, we can see that the temperature of the food items and hot water with initial temperature of around $64 \mathrm{degC}$ reaches an average of $60.4 \mathrm{degC}$ after 150 minutes after adding hot water in the glass wool insulated box. After this the water in the box needs to be replaced by fresh hot water from solar water heater.

a. Glass wool Insulation

Table 3: Temperature Vs. Time reading for different food items with glass wool insulation

\begin{tabular}{|l|l|l|l|l|l|l|l|l|}
\hline $\begin{array}{l}\text { Material/ } \\
\text { Time }\end{array}$ & $\begin{array}{l}\mathrm{T}=0 \\
\text { mins }\end{array}$ & $\begin{array}{l}\mathrm{T}=15 \\
\text { mins }\end{array}$ & $\begin{array}{l}\mathrm{T}=30 \\
\text { mins }\end{array}$ & $\begin{array}{l}\mathrm{T}=45 \\
\text { mins }\end{array}$ & $\begin{array}{l}\mathrm{T}=60 \\
\text { mins }\end{array}$ & $\begin{array}{l}\mathrm{T}= \\
90 \\
\text { mins }\end{array}$ & $\begin{array}{l}\mathrm{T}= \\
\text { mins }\end{array}$ & $\begin{array}{l}\mathrm{T}= \\
\text { mins }\end{array}$ \\
\hline WATER & 60 & 59.6 & 59 & 57.9 & 57 & 56 & 55.5 & 55 \\
\hline RICE & 68 & 67 & 66 & 65 & 64 & 63 & 63 & 62 \\
\hline POTATO & 59 & 59 & 59 & 56.5 & 56 & 55.5 & 55 & 54.5 \\
\hline CURRY & 59 & 58.5 & 58 & 58 & 58 & 57 & 56 & 55 \\
\hline FACE 1 & 54.3 & 57.1 & 56.4 & 55.5 & 54.4 & 53.3 & 53 & 52 \\
\hline
\end{tabular}




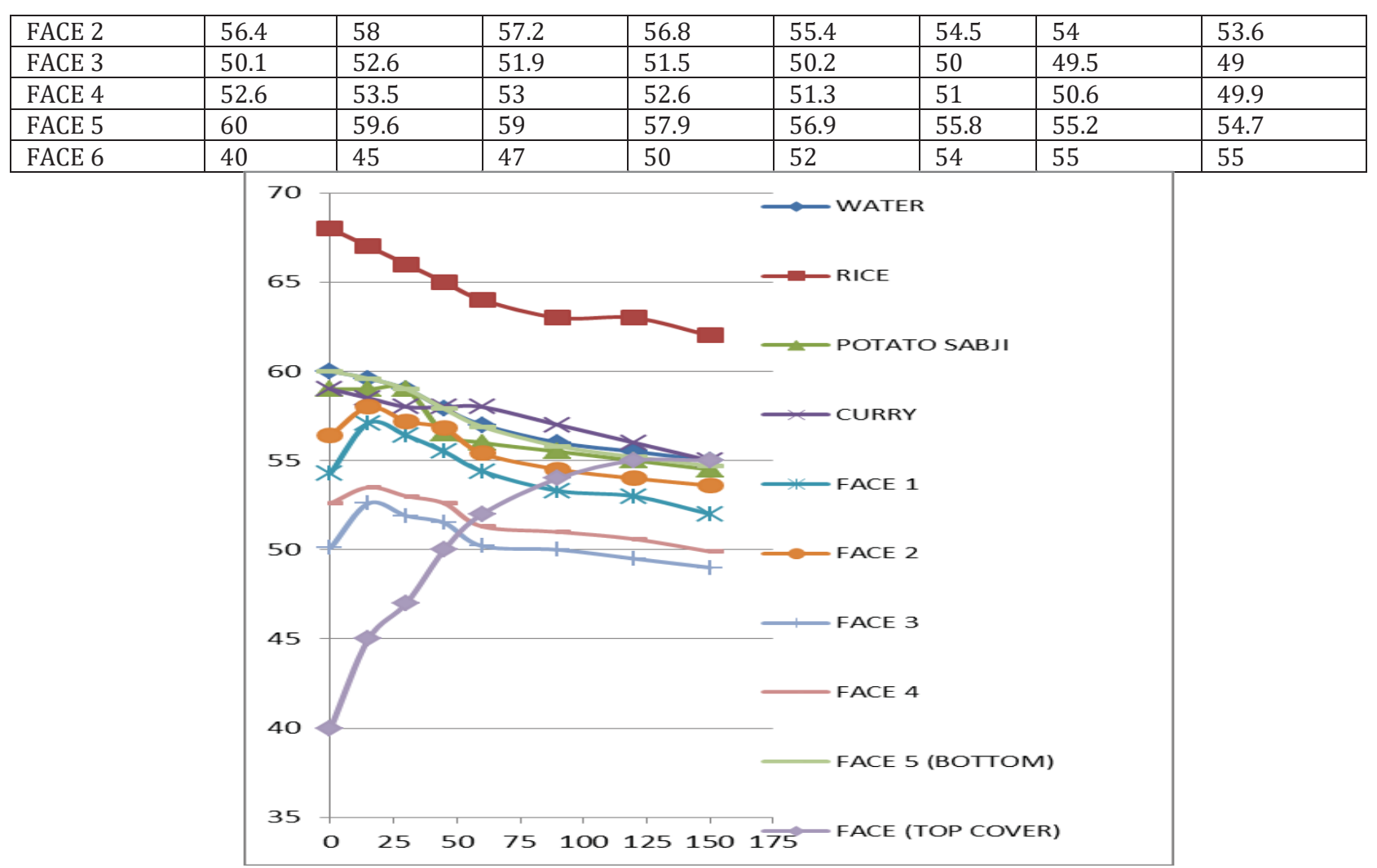

Figure 4: Graph showing temperature of food items against time with glass wool insulation

From the above observation, we can see that the temperature of the food items and hot water with initial temperature of $60 \mathrm{degC}$ reaches an average of $55 \mathrm{degC}$ after 150 mins after adding hot water in the glass wool insulated box. After this the water in the box needs to be replaced by fresh hot water from solar water heater.

Table -4 Experiment Result

\begin{tabular}{|c|c|c|c|c|c|}
\hline $\begin{array}{c}\text { Sr. } \\
\text { No. }\end{array}$ & Insulation & $\mathrm{q}\left(\mathrm{W} / \mathrm{m}^{\wedge} 2\right)$ & $\mathrm{Q}(\mathrm{W})$ & $\begin{array}{c}\text { \% HEAT LOSS } \\
\text { REDUCTION }\end{array}$ & $\begin{array}{c}\text { \% REDUCTION IN RATE OF } \\
\text { HEAT LOSS }\end{array}$ \\
\hline 1 & No Insulation & 3.37 & 37.99 & - & - \\
\hline 2 & Glasswool & 2.11 & 22.57 & $37.44 \%$ & $40.59 \%$ \\
\hline 3 & Polystyrene & 1.57 & 18.00 & $53.45 \%$ & $52.62 \%$ \\
\hline
\end{tabular}




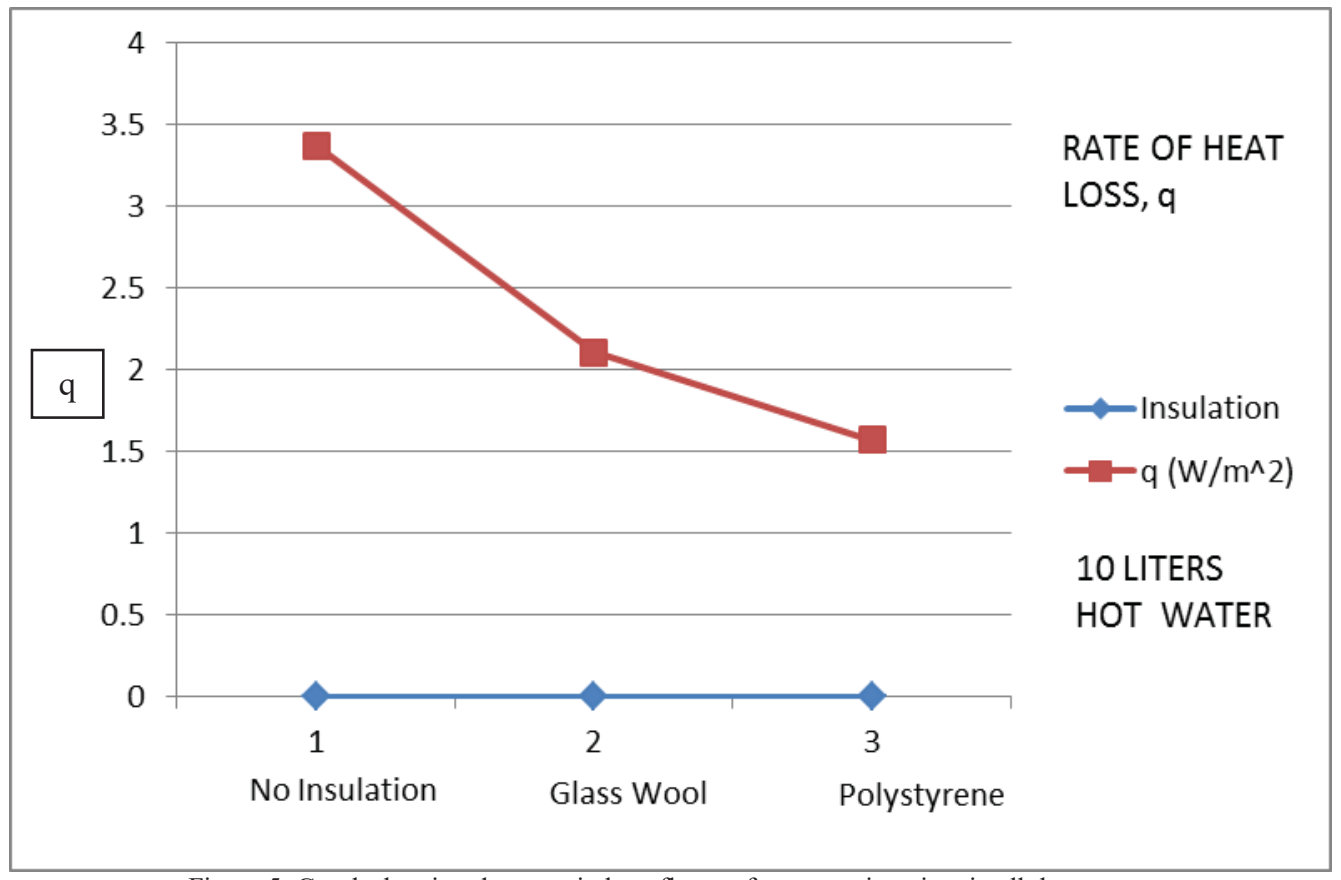

Figure 5: Graph showing decrease in heat flux,q of setup against time in all three cases

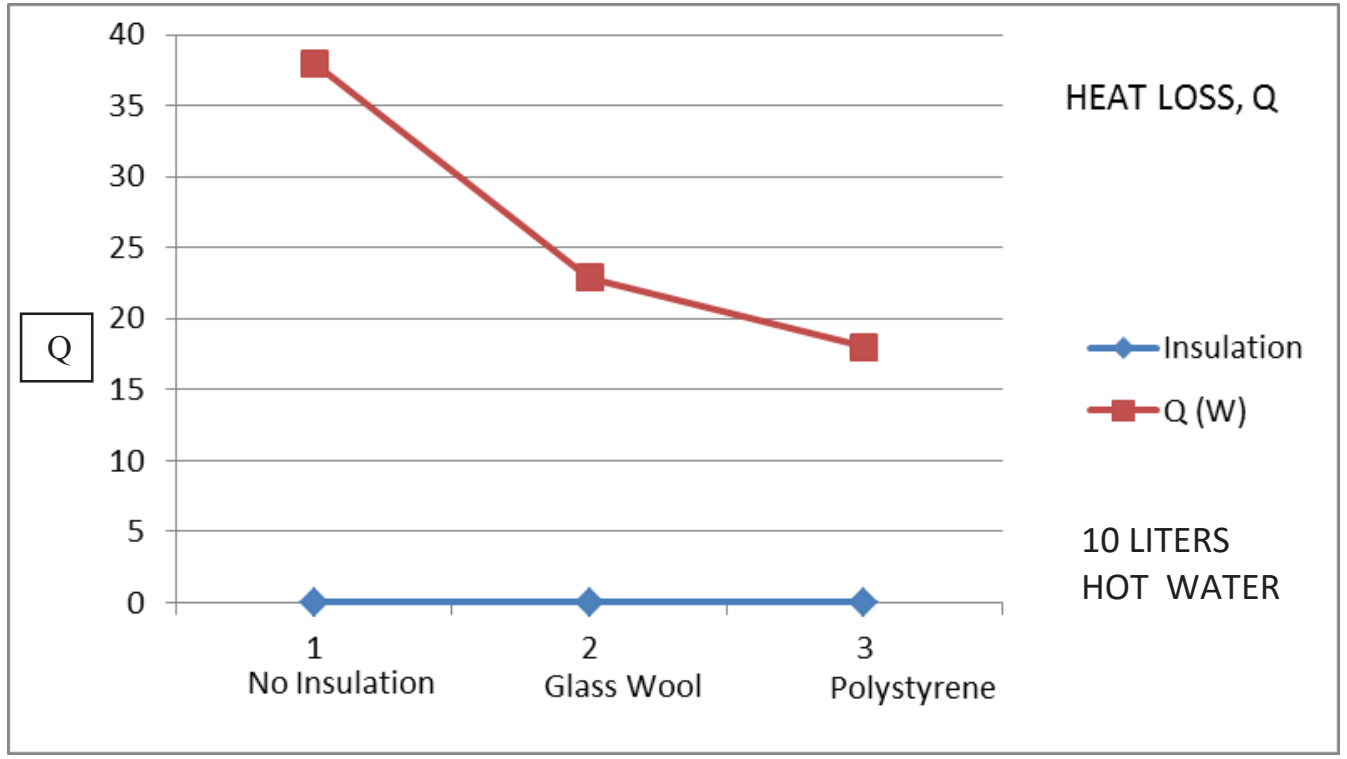

Figure 6: Graph showing decrease in heat loss, $\mathrm{Q}$ of setup against time in all three cases

It can be found out from the graph that the heat loss was maximum with no insulation. With glass wool insulation the heat loss reduced to some extent and with polystyrene insulator the heat loss reduced to $53.45 \%$ as compared to case of no insulation. Also, the heat flux was maximum when the setup was used without insulation and least when polystyrene insulator was used. Total reduction in heat flux was $52.62 \%$.

\section{IV.CONCLUSION}

a. It can be found that after using Glasswool the Rate of Heat Loss was reduced by $49.59 \%$ and Heat Loss from the setup was reduced by $37.44 \%$

b. After using polystyrene as the insulating material for same 10 liters of hot water, it was found that Rate of Heat Loss was cut down by $52.62 \%$ and Heat Loss from the setup was reduced by $53.45 \%$ 


\section{REFERENCES}

[1] Shangli Shan,et.al (2006), Advances in the Research of Heat Pump Water Heaters, ICEBO2006, Shenzhen, China, Renewable Energy Resources and a Greener Future Vol.VIII-12-2

[2] Vishwanath K Patel (2012), Solar Energy Scenarios; IOSR Journal of Mechanical and Civil Engineering (IOSRJMCE), ISSN : $2278-1684$ Volume 1, Issue 2 (July-Aug 2012), PP 01-03

[3] Xingxing Zhang,et.al, Novel Solar Assisted Water Heating System with Enhanced Energy Yield for Buildings, ESL-IC-12-10-33

[4] Pankaj D. Menghani, et.al(2014); Low Pressure Steam Generation by Solar Energy with Fresnel Lens : A Review, IOSR Journal of Mechanical and Civil Engineering (IOSR-JMCE), ISSN: 2278-1684, PP: 60-63

[5] Saurabh Deshmukh, et. al(2014), Solar Power Generation and Wireless Power Transmission System, IOSR Journal of Electrical and Electronics Engineering (IOSR-JEEE), e-ISSN: 2278-1676,p-ISSN: 2320-3331, Volume 9, Issue 4 Ver. II (Jul - Aug. 2014), PP 14-18

[6] S. Ramanan \& R. Sridharan(2013), Solar Energy in India - a Motivation for Engineering Undergraduates, IOSR Journal of Research \& Method in Education (IOSR-JRME), e-ISSN: 2320-7388,p-ISSN: 2320-737X Volume 2, Issue 6 (Jul. -Aug. 2013), PP 27-30

[7] Vijay Talekar et.al; Performance Improvement of Solar PV Panel Using Reflectors and Bi-Axial Tilting Mechanism; IOSR Journal of Mechanical and Civil Engineering (IOSR-JMCE); e-ISSN: 2278-1684, p-ISSN: 2320-334X

[8] KamaruzzamanSopian; MohdYusof Othman; Saleem H. Zaidi; Advances In Solar Assisted Drying Systems ForMarineland and Agricultural Products.

[9] M.Y.H. Othman, K. Sopian , B. Yatim (2006), W.R.W. Daud, Development of advanced solar assisted drying systems, Renewable Energy 31 (2006) 703-709.

[10] Kishan Patel, Mrs. Pragna Patel, and Mr. Jatin Patel; Review of Solar Water Heating Systems.

[11] Nahar,N.M. (2003), Year round performance and potential of a natural circulation type of solar water heater in India. Energy and Buildings 2003, 35, 239-247.

[12] Norton B(2006), Lo, S. Anatomy of a solar collector. Refocus 2006, May/June, 32-35.

[13] Houri, A (2006). Solar water heating in Lebanon: current status and future prospects. Renewable Energy 2006, 31, 663-675. 